\title{
Storage and release of fossil organic carbon related to weathering of sedimentary rocks
}

\author{
Yoann Copard ${ }^{\text {a, }}$ Philippe Amiotte-Suchet ${ }^{\text {b, }}$ and Christian Di-Giovanni ${ }^{c}$, \\ ${ }^{a}$ UMR 6143 du CNRS, Morphodynamique Continentale et Côtière, Département de Géologie, \\ Université de Rouen, 76821 Mont Saint Aignan Cedex, France \\ ${ }^{\mathrm{b}}$ UMR A 1229 INRA, Microbiologie et Géochimie des Sols, Université de Bourgogne, Centre \\ des Sciences de la Terre, 6 bd Gabriel, 21000 Dijon, France \\ ${ }^{c}$ UMR 6113 du CNRS, Institut des Sciences de la Terre d'Orléans, Bâtiment Géosciences, rue \\ de St Amand, BP 6759, 45067 Orléans Cedex 2, France
}

\begin{abstract}
The biogeochemical carbon cycle, which plays an undeniable role in global climate change, is defined both by the size of carbon reservoirs (such as the atmosphere, biomass, soil and bedrock) and the exchange between them of various mineral and organic carbon forms. Among these carbon forms, fossil organic carbon (FOC) (i.e., the ancient organic matter stored in sedimentary rocks) is widely observed in modern environments but is not included in the supergene carbon budget. Using a digitized map of the world and an existing model of $\mathrm{CO}_{2}$ consumption associated with rock weathering, we establish the global distribution of FOC stored in the first meter of sedimentary rocks and a first estimation of annual FOC delivery to the modern environment resulting from chemical weathering of these rocks. Results are given for the world's 40 major river basins and extended to the entire continental surface. With a mean value of $110010^{9} \mathrm{t}$, mainly controlled by shale distribution, the global FOC stock is significant and comparable to that of soil organic carbon $\left(150010^{9} \mathrm{t}\right)$. The annual chemical delivery of FOC, estimated at $4310^{6} \mathrm{t} \mathrm{yr}^{-1}$ and controlled by the areal distribution of shales and runoff, is of the same order of magnitude as the FOC output flux to oceans. Chemical weathering of bedrock within the Amazon basin produces one-quarter of the total global flux of FOC derived from chemical weathering, and thus is expected to govern FOC release on a global scale. These results raise important questions concerning the role of FOC in the modern carbon cycle as well as the origin and the budget of carbon in soils and rivers.
\end{abstract}

Keywords: global carbon cycle; spatial distribution; major river basins; weathering; fossil organic carbon flux; fossil organic carbon storage 


\section{Introduction}

Fossil organic carbon (FOC) is derived from ancient organic matter (OM) (kerogen, in the language of petroleum geologists) buried with mineral matter in sedimentary basins. During burial, time, temperature, and pressure affect the chemical and physical properties of OM until a graphitic form is attained [1]. In the right geological setting, and especially where uplift has occurred, sedimentary rock bearing this ancient OM and its corresponding FOC can outcrop at the continental surface. FOC then can be delivered to modern environments through the mechanical erosion and chemical weathering of these sedimentary rocks (Fig. 1). Previously, the role of FOC in modern environments was considered only in the context of a carbon balance (i.e., to balance the burial of organic carbon through the total mineralization of FOC at outcrop), with an annual flux of $10010^{6} \mathrm{t}$, and hence to maintain a constant atmospheric level of $\mathrm{O}_{2}$ and $\mathrm{CO}_{2}$ [2]. However, because a part of this $\mathrm{FOC}$ escapes from diagenetic processes during the geological cycle, it is believed also to be partially recalcitrant to mineralization at outcrop.

FOC has been identified as being ubiquitous in rivers [3], [4], [5] and [6] and, more recently, in soils [7], and even in recent marine sediment [8] and [9]. In light of these observations, it is extraordinary that FOC has never been quantified in the supergene organic carbon budget (Fig. 1, [10], [11] and [12]). Only two studies propose an annual estimate of FOC delivery to the world's oceans, one describing delivery by world river basins $\left(8010^{6} \mathrm{t} \mathrm{yr}^{-1},[13]\right)$ and the other by small mountainous rivers $\left(4010^{6} \mathrm{t} \mathrm{yr}^{-1}\right.$, [14], Fig. 1). Other authors have suggested that on the order of $40-7010^{6} \mathrm{t} \mathrm{yr}^{-1}$ of FOC may be reburied [15]. There currently is no quantitative information available regarding the transport of FOC by rivers before its delivery to the oceans. Providing meaningful global-scale data concerning the contribution of FOC from the continental surface is not straightforward. This shortcoming is aggravated by the lack of distinction between FOC and black carbon (the combustion residue of fossil fuel and present vegetation [16]), which, to a certain extent, invalidates estimates of these types of inert carbon [8]. In determining the contribution of FOC to modern environments, the initial step in the delivery of FOC - i.e., its release through mechanical erosion and chemical weathering of sedimentary rocks from its storage in the upper part of these (sub)-outcropping rocks - must be considered (Fig. 1). One study claims that the chemical weathering of carbonates and shales produces $10010^{6} \mathrm{t} \mathrm{yr}^{-1} \mathrm{FOC}$ [17], partitioned between soils, rivers, and, through mineralization, the atmosphere, and no data exist for the amount of FOC produced by mechanical erosion except for that produced by small mountainous watersheds $\left[4010^{6} \mathrm{t} \mathrm{yr}^{-1}, 14\right]$.

Here we present an estimate of the FOC flux contributed by the chemical weathering of sedimentary rocks. We use a GIS survey to estimate the original FOC stock contained in the upper layers of sedimentary rocks for the world's 40 major river basins, and extend it to the entire continental surface. We then estimate the FOC flux attributable to the chemical weathering of carbonates and shales, and its distribution for the watersheds studied and on a global scale. These initial results might provide a useful starting point for further investigations concerning the contribution of FOC to continental surfaces and hence to the supergene carbon cycle. 


\section{Methods}

The general approach used here was to calculate the amount of FOC in storage and the FOC yield originating from the chemical weathering of shales and carbonates for the whole continental surface, and then to calculate average budgets for the world's 40 major river basins. Numerical maps of FOC storage and FOC chemical yield were established at the global scale using GIS software at a $1^{\circ} \times 1^{\circ}$ grid resolution and world maps of river basin limits, continental rock lithology [18], and continental runoff [19]. The global distribution of the lithology used divides sedimentary rock into three simplistic categories: carbonates (defined as all rocks with more than $50 \%$ of carbonate minerals), shales (defined as poorly carbonated clastic and argillaceous sediments), and sands/sandstones (i.e., sandy sediments with various origins).

The spatial distribution of FOC in the first meter of sediment (Fig. 2) was calculated for each $1^{\circ} \times 1^{\circ}$ grid cell on the basis of the average carbon content for sedimentary rocks [20] and the density [21] of carbonates, shales, and sandstones/sands (Table 1). Because the model is run at the global scale, it is assumed that local changes in total organic carbon values and rheologic behavior of a rock type will be smoothed. The FOC amount stored within the world's 40 largest drainage basins was calculated in units of $10^{9} \mathrm{t}$ (Table 2) or in $\mathrm{t} \mathrm{km}^{-2}$ (as Fig. 2), combining the numerical FOC map (Fig. 2) with river basin limits.

Excepted area, all parameters are from the compilation of Amiotte-Suchet et al. [18]; values of Mehandi river basin: lithological abundance [68], areal extent and runoff [19].

Evaluation of the chemical FOC yield requires the average FOC contents and densities of the carbonate and shales (Table 1). Input of FOC to modern environments from rock weathering was estimated using GEM-CO $\mathrm{CO}_{2}$, an approach that models $\mathrm{CO}_{2}$ consumption by chemical weathering of rocks to calculate weathering rates [22]. For carbonate and silicate minerals, chemical weathering mainly is controlled by acid hydrolysis reactions with soil $\mathrm{CO}_{2}$, which then is released in solution as $\mathrm{HCO}_{3}{ }^{-}$[18]. Therefore, for a given rock type, the chemical erosion flux $\left(\mathrm{F}_{\mathrm{W}}\right.$ in mol km $\left.\mathrm{km}^{-2} \mathrm{~s}^{-1}\right)$ is proportional to the $\mathrm{CO}_{2}$ consumption and can be calculated as follows:

$$
\begin{gathered}
\mid F_{W}=\sum\left(F_{W}^{X}\right) \\
F_{W}^{X}=R^{X} \cdot I_{\mathrm{CO} 2} \cdot Q
\end{gathered}
$$

where $R^{X}$ is the molar quantity of chemical compound $X$ released by rock weathering for one mole of soil $\mathrm{CO}_{2}$ consumed, and is determined using the average chemical composition of stream-draining single rock types [23]. $I_{\mathrm{CO} 2}$, referred to as the weathering index, is the rate of $\mathrm{CO}_{2}$ consumed by chemical weathering of a given rock (in mol ${ }^{-1}$ ) under the same weathering conditions derived from the GEM- $\mathrm{CO}_{2}$ model. It is based on the relation between $\mathrm{CO}_{2}$ consumption by rock weathering and runoff for single rock types [24]. Q is the drainage intensity [19] (in $1 \mathrm{~km}^{-2} \mathrm{~s}^{-1}$ ).

The mass of rock weathered (and thus the amount of FOC input to the modern environment) is estimated taking into account the average insoluble residue $(R)$ as follows:

$$
\mid M_{w}=a \cdot F_{W}^{X}
$$


with:

$$
\underline{a=100 /(100-R)}
$$

Finally, the amount of FOC input to the modern environment $\left(F_{\mathrm{FOC}}\right)$ is calculated as follows:

$$
\underline{F}_{\mathrm{FOC}}=b \cdot \underline{M}_{\underline{w}}
$$

where $b$ is the FOC content of sedimentary rocks. The weathering of shales, which have an insoluble residue of $94 \%$ [25], was assumed to release $\mathrm{Ca}^{2+}, \mathrm{Mg}^{2+}, \mathrm{Na}^{+}, \mathrm{K}^{+}$, and $\mathrm{SO}_{4}{ }^{2-}$, whereas the weathering of carbonate rocks, which have an insoluble residue of $24.2 \%$ [20], was assumed to release only $\mathrm{Ca}^{2+}$ and $\mathrm{CO}_{3}{ }^{2-}$. For these calculations, sands/sandstones were not considered, as they were assumed to be largely insoluble and consume very little $\mathrm{CO}_{2}$ during chemical weathering [24].

\section{Results}

\subsection{FOC at the continental surface: Global storage and distribution}

We estimated the FOC stored in the first meter of sedimentary rocks for the world's 40 major watersheds $\left(50.210^{6} \mathrm{~km}^{2}\right)$. The choice of a thickness of $1 \mathrm{~m}$ was dictated by the need for comparison with the storage of organic carbon in soils, which usually is assessed for this same thickness [10]. As the numerical map $\left(1^{\circ} \times 1^{\circ}\right.$; Fig. 2) indicates, the global distribution of FOC stocks is heterogeneous, and values for each grid cell differed accordingly: 22 (shales), 7 (carbonates), and 5 (sands/sandstones) $10^{3} \mathrm{t} \mathrm{km}^{-2}$. These values are related to the average FOC content of these rock types (Table 2). The absence of FOC in a large part of North America, northern Europe, western Siberia, the main part of India, and South America is understandable as their bedrock is composed of shield rocks, acid volcanic rocks, and basalts, which are devoid of FOC. For the river basins, the overall stock of FOC is about $44810^{9} \mathrm{t}$, and at the global scale, this stock reaches a value of $110010^{9} \mathrm{t}$ (Table 2). Using existing data on lithologic abundance and surface watersheds [18], our modelling indicates that the Amazon, the world's largest drainage basin $\left(5.84610^{6} \mathrm{~km}^{2}\right)$, stores the largest amount of fossil carbon $\left(>7310^{9} \mathrm{t}\right)$, followed by the basins of the $\mathrm{Ob}\left(5110^{9} \mathrm{t}\right)$, the Mississippi (41 $10^{9} \mathrm{t}$ ), the Parana $\left(3210^{9} \mathrm{t}\right)$, and the Lena $\left(2210^{9} \mathrm{t}\right)$ (Table 2). These five watersheds contain $40 \%$ of the FOC stored in the 40 watersheds but make up only about $30 \%$ of the total surface area considered. Conversely, the Zaire basin, although considered to be the second major watershed in terms of area $\left(3.710^{6} \mathrm{~km}^{2}\right)$, stores only $1210^{9} \mathrm{t}$, and the Yenisei, which is larger than the Lena basin, stores only $810^{9}$ t. This is explained by a relatively low abundance of shale in these watersheds ( 0 and $16.1 \%$ for the Zaire and Yenisei basins, respectively). Thus, at both basin and global scales, shales, because of their high FOC content (1\%), exert a strong control on the amount and distribution of the stock of FOC (Fig. 2, Table 2).

\subsection{FOC chemical input and global distribution}

On its own, the large amount of FOC stored in the first meter of sedimentary rock is insufficient evidence for a significant FOC contribution to the supergene carbon cycle. Rather, its importance in this cycle is controlled strongly by the dual chemical 
weathering/mechanical erosion affecting these rocks, which deliver their FOC content to modern environments (soils, rivers, and the atmosphere). Using GEM- $\mathrm{CO}_{2}$ modelling [22], we present a world map of FOC yield resulting from the chemical weathering of shales and carbonates (Fig. 3). The map, with grid cells values ranging from 0 to $11710^{3} \mathrm{t} \mathrm{yr}^{-1}$, shows a heterogeneous distribution different from that of the FOC stock. Although the map presents strong evidence for shale distribution as a major factor controlling FOC yield, because of the large proportion of insoluble residue associated with shales compared to that associated with carbonates (Table 1), two other parameters must be considered: the chemical weathering index of sedimentary rocks, and runoff [24]. If the chemical weathering index is fixed and is greater for carbonates than for shales, runoff acts as a positive feedback in rock weathering [22] and [24], and consequently in the delivery of FOC.

The roles of runoff and the areal extent of shales are illustrated in Fig. 4a and b, respectively. From a general point of view, the importance of runoff is attested to by the coefficient of determination $r^{2}$ (0.94, Fig. 4a) and the Pearson test ( $\alpha$ threshold $\left.=0.050, r=0.97\right)$. However the greater importance of runoff compared to the areal extent of shales is due to the Amazon drainage basin; if the Amazon is not included, the coefficients of determination are quite similar 0.66 for runoff and FOC, and 0.647 for shale surface area and FOC.

The importance of runoff on FOC release is apparent. This is illustrated by the comparison of the Don and Orinoco river basins, which have a similar areal extent of shale: 363.8 and 454.1 $10^{3} \mathrm{~km}^{2}$, respectively, and a small areal extent of outcropping carbonate (22.8 and 12.6 $10^{3} \mathrm{~km}^{2}$, Table 2). The total FOC yielded by the Orinoco. however, is nearly nine times greater than that yielded by the Don drainage basin $\left(0.749\right.$ and $0.08410^{6} \mathrm{t} \mathrm{yr}^{-1}$, respectively). This large discrepancy is unambiguously correlated to their runoff values, i.e., $759 \mathrm{~km}^{3} \mathrm{yr}^{-1}$ for the Orinoco and only $31 \mathrm{~km}^{3} \mathrm{y}^{-1}$ for the Don [18], whose drainage basin is in a dry temperate climate [11]. Two drainage basins with a dry tropical climate (the Nile and the Niger, [11]) do not show the same trend as the other basins; the different values for these two African drainage basins result from the low areal extent of shale and carbonate outcrops (Table 2).

The FOC input to the continental surface also is a function of the areal extent of shales (Fig. $4 \mathrm{~b}$ ), which is not surprising given their high FOC content. As an extreme example, the Niger and Yukon drainage basins, which have similar runoff values (166 and $169 \mathrm{~km}^{3} \mathrm{yr}^{-1}$, respectively) and a small areal extent of carbonate outcrops, have very different FOC fluxes (Table 2). The FOC produced by the Yukon basin is 220 times greater than that of the Niger ( 0.440 vs. $0.00210^{6} \mathrm{t} \mathrm{yr}^{-1}$, respectively), resulting from the fact that the Yukon basin has a large proportion of shales $\left(85.4 \%\right.$ of its total area, i.e., $\left.696.810^{3} \mathrm{~km}^{2}\right)$, whereas the Niger basin is devoid of shales (Table 2). However, the relation between the areal extent of shales and FOC yield is less strong than that between runoff and FOC yield, as indicated by the Pearson test $(r=0.74)$ and the coefficient of determination between shale surface area and FOC input $\left(r^{2}=0.55\right.$, Fig. $\left.4 b\right)$.

The strong relation between runoff and FOC yield explains why the global distribution of FOC stock and its release do not coincide spatially (Fig. 2 and Fig. 3). The total annual FOC yield for the 40 drainage basins combined is $20.0410^{6} \mathrm{t}$, which corresponds to about half of the total global annual yield $\left(42.9010^{6} \mathrm{t}\right)$. With an annual FOC yield of $10.7410^{6} \mathrm{t}$, the Amazon watershed delivers the single greatest amount of FOC to continental surfaces. The FOC yield from the Amazon drainage basin is substantially higher than those of other major 
basins such as the Ganges-Brahamaputra, the Ob, the Mississippi, or the Parana, which, at

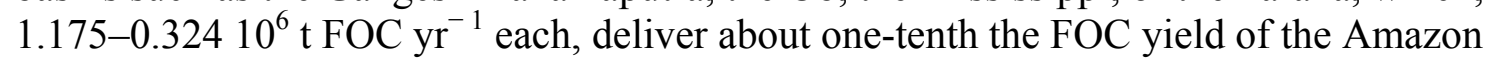
basin. The Congo basin is excluded as there is no shale outcropping in its watershed. The high delivery by the larger drainage basins corresponds to one-half of the total FOC delivery yielded by the 40 drainage basins examined.

At the global scale, on the basis of our results, it is expected that a quarter of the FOC released to the Earth's surface is produced by the Amazon drainage basin. In turn, this exceptional contribution implies that chemical weathering occurring in the Amazon area governs the FOC flux originating from the chemical weathering of shales and carbonates within the world's continental surfaces.

\section{Discussion}

The data provided by the model can be compared to other values of OC in general and to FOC fluxes in continental surfaces in particular. Such a comparison is essential for evaluating whether the model results are meaningful and for determining the major implications. A useful approach is to evaluate the model results in the context of the global FOC transport budget. The transport of FOC from continental surfaces toward the world's oceans can be expressed as:

$$
\begin{array}{|}
\mid A+B+C-D-E=8010^{6} \mathrm{t} \mathrm{yr}^{-1} \\
\text { FOC export to the world's oceans }
\end{array} \mid
$$

[13]where

$A$

supply from chemical weathering of rocks $\left(43-10010^{6}{\left.\mathrm{t} \mathrm{yr}^{-1}\right)}^{-1}\right.$

$B$

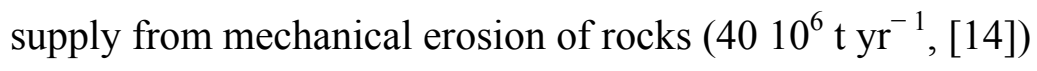

$C$

supply from remobilisation of floodplain sediments

$D$

deposition in continental surface reservoirs

$E$

depletion by mineralization

The model presented here provides the flux of FOC yielded by the chemical weathering of rocks, that is, term A in the FOC budget. 


\subsection{FOC inputs from weathering and erosion of continental rocks}

The first two terms in Eq. (6) express the supply of FOC from chemical weathering and mechanical erosion of rocks. The first meter of continental rocks contains a stock of FOC close to $110010^{9} \mathrm{t}$, and hence is comparable to that of total soil organic carbon $\left(150010^{9} \mathrm{t}\right.$, [10]). Soils develop at the expense of the underlying rock, and FOC has been observed in soils, fluvial sediment, and lacustrine sediment using optical [26], [27], [28], [29] and [30] and geochemical [28] and [31] markers. The amount of FOC in soil organic carbon likely is significant but has not yet been quantified.

The model presented here provides an estimate of FOC contributed to the global FOC budget from the chemical weathering of rocks (term A in Eq. (6)). This estimate can replace the previous value [17] of term A in Eq. (6). The FOC flux determined from our model $\left(4310^{6} \mathrm{t}\right.$

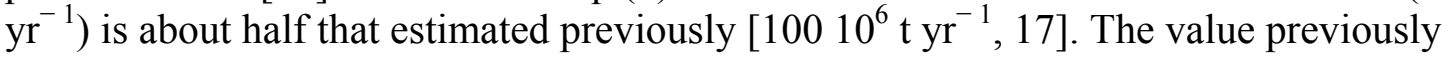
calculated was an initial and simplistic attempt that relied largely on approximations based on the extrapolation of results from watersheds to climatic zones and from watersheds to the global scale without taking into consideration the existing rock types. For that reason, we believe the results provided by our model, which takes into account rock type, chemical alteration, and runoff, are more reliable.

The mechanical erosion of rocks contributes to the FOC flux leaving the continents (term B in Eq. (6)). Evidence of FOC resulting from the erosion of sedimentary rocks has been found in fluvial and marine sediment using radiocarbon measurements. For example, the occurrence of FOC in fluvial sediment has been widely documented for rivers draining small mountainous coastal catchments in active margin contexts, where topographic relief favors slope processes such as landslides and mass movements, e.g., in California [9], [14] and [32], New Zealand [33] and Taiwan [4]. The occurrence of FOC also been documented for passive margin rivers, for example rivers in the northeastern U.S. [5] and [6], and the Rhine River [34].

The FOC flux contributed by the mechanical erosion of rocks has been estimated at about 40 $10^{6} \mathrm{t}$ by Blair et al. [14]. This flux was obtained by extrapolating the flux from a small river in California (the Eel River) to small rivers at the global scale. This estimate assumes that the material eroded does not undergo deposition or mineralization (terms D and E in Eq. (6)), but rather is delivered directly to the oceans. This flux is very similar to that estimated by our model for the chemical weathering of rocks, indicating that the FOC flux provided to the supergene carbon cycle by chemical weathering and mechanical erosion are roughly equal in important.

The FOC flux from mechanical erosion estimated by Blair et al. [14] must be considered a minimum, as they considered only erosion from small river basins, and did not include erosion from the world's large river basins. Although large drainage basins are believed to contribute FOC to the world's oceans, this amount has yet to be quantified, largely because the methods used (e.g., radiocarbon and isotopic analyses) were poorly suited for the quantification of FOC. For example, sources of sediment in the Gulf of Mexico include either erosion of sedimentary rocks in the Mississippi basin [35] and/or erosion of younger soils [36]; the mix of sources, by which modern and terrestrial OM dilutes FOC, prevents FOC quantification or even characterization. Such uncertainties, however, can be resolved through use of other methods. For example, particulate OM microscopy, was successfully applied to the analysis of sediment from the Gulf of Lion (mainly Rhône sediments) [37]. 
The relative contributions of chemical weathering and mechanical erosion vary greatly depending on the characteristics of the river basin. For example, for the watershed of the Huang He River, the flux of FOC contributed by erosion (term B) greatly exceeds that contributed by chemical weathering (term A). Total FOC export from the Huang $\mathrm{He}$ watershed to the ocean is estimated at $410^{6} \mathrm{t} \mathrm{yr}^{-1}$ [Meybeck, pers. com.], which greatly exceeds the contribution from chemical weathering along estimated from our model for this river $\left(0.00410^{6} \mathrm{t} \mathrm{yr}^{-1}\right)$. The difference arises from the substantial occurrence of loess in the watershed [38], which Meybeck estimated to contain $0.5 \%$ FOC by weight, and which erodes easily even in the absence of substantial topographical relief. Thus even in cases where the contribution of FOC by chemical weathering (term A) is negligible, the release of FOC from sedimentary rocks (the sum of terms A and B) can be substantial if there is a high amount of erosion. Export of FOC to the marine environment by erosion also is enhanced when part of a watershed is subject to gully erosion of sedimentary rocks. Although this phenomenon can be highly localized, it can dominate the load of eroded material. This type of erosion was demonstrated for the Waipaoa River [33], and hypothesized for the Rhone River [39]. One of the main Rhone tributaries, the Durance River, includes a large area of badlands facies, which favor gully erosion [40]. This hypothesis is reinforced by the comparison of optical and geochemical signatures of OM in suspended loads with those of bedrock in small basins within the Durance watershed [27] and [31].

The total contribution from the chemical and mechanical weathering of rocks to the world's oceans ( $\mathrm{A}+\mathrm{B}$ in Eq. (6), equal to $8310^{6} \mathrm{t} \mathrm{yr}^{-1} \mathrm{FOC}$ ) is very similar to that estimated by Meybeck for the total export to the world's oceans (the right side of Eq. (6), $8010^{6} \mathrm{t} \mathrm{yr}^{-1}$, [13]). Meybeck's estimate is the single estimate available of global FOC flux exported to the world's oceans. This estimate, however, accounts for all the processes included in Eq. (6), and thus cannot be reasonably compared simply to the sum of terms A and B. Instead, the contribution of FOC from the remobilization of floodplain sediment and the removal of FOC by mineralization and redeposition must be evaluated. Specifically, to quantify the remaining contributions to the global FOC transport budget (terms C, D, and E in Eq. (6)), several questions remain to be addressed: Does chemical weathering substantially contribute to particulate FOC found in rivers? What is the proportion of FOC in dissolved OC? How can we estimate the FOC flux associated with remobilization and mineralization? Consequently, great uncertainty surrounds the fate of FOC in modern environments after its release.

\subsection{Fate of FOC: Remobilization, storage, and mineralization}

Little research exists that quantifies or even provides examples of remobilization of FOCcontaining sediment (term $\mathrm{C}$ of the Eq. (6)), although common sense suggests that it must occur. However, deposition and storage of FOC and FOC mineralization (terms D and $\mathrm{E}$ in Eq. (6)) are better understood, and to an extent explain the difference between the results provided by our model for a given watershed and the FOC output to the marine environment.

Among the numerous fates that FOC in continental rocks can undergo leading to mineralization, three can be considered as major on the basis of the quantity of FOC delivered to the atmosphere, to soils, and to rivers (Fig. 1). First, FOC can be entirely mineralised from the rock, releasing $\mathrm{CO}_{2}$ to the atmosphere. Complete oxidation of FOC, however, is unrealistic, as the occurrence of FOC is widely recognised in all modern environments (see Introduction and Discussion sections for numerous references). Second, because soils develop at the expense of underlying rock, FOC from rocks can become mixed with SOC [7], [31] and [33]. It is essential that the FOC in soils be accounted for in the global FOC budget. Finally, 
FOC can be released in rivers as shown for two experimental watersheds [31], where it was demonstrated that the rock-to-stream flux qualitatively and quantitatively preserves FOM. Once in the fluvial system, FOC can be mineralized. The amount of fluvial particulate organic carbon (POC) derived from autochthonous production and diverse allochthonous sources, including aged soils, resuspension of floodplain sediment, and rock-derived FOC, remains to be quantified. Mineralization of FOC in fluvial systems, however, likely would be attenuated, because of its association with mineral surfaces, such as fine clayey particles in suspension [14], [41], [42] and [43]. The preservation of FOC once in fluvial systems supports the hypothesis that FOC must contribute substantially to the amount of continental organic carbon delivered annually to the world's oceans [14] and [23], provided that some part of FOC does not undergo storage in soils or in recent continental sediments in floodplains.

Mineralization of organic carbon results mainly from oxidation by air, hydrolysis, and bacterial consumption, referred to together as (bio)geochemical weathering. (Bio)geochemical weathering of recalcitrant organic carbon, as FOC, occurs in soils, by-pass compartments (e.g., continental sediments), rivers, and recent ocean sediment. The last is illustrated by the weathering of black carbon - a form of OC even more recalcitrant and supposedly inert than FOC [16] - observed in turbidites [44]. Although evidence of FOC mineralization has been demonstrated [45], the amount of FOC mineralised remains difficult to establish [e.g., [31]], except for FOC in outcropping coal seams [46], [47] and [48], where mineralization of FOC ranges from $20 \%$ to $45 \%$ [46] and [48] or black shales, where mineralization of FOC is total [45].

The physico-chemical properties of organic matter containing FOC control the proportion of labile and recalcitrant organic compounds undergoing a given mineralization process. These properties depend on the origin of the organic matter [49] and on its maturity [1]. As an example, the contrasting behaviour of geochemical markers during mineralization suggests that for soils, the greater the richness in hydrogenated components, the more rapid the mineralization [31] and [50].

Mineralization of FOC depends on the aggressiveness of the extrinsic factors promoting the mineralization, including water, oxygen concentration, and efficiency of the bacterial consortium for the degradation of organic compounds. The aggressiveness of these parameters is controlled by climate, geomorphology, and, since the Anthropocene, anthropogenic activities. Land-use changes resulting from human activities (e.g., deforestation, reforestation, and dams [e.g., [51] and [52]]) can act either to amplify or moderate the effects of climate and geomorphology on mineralization. For example, the reforestation of the Huang He River watershed decreased the sediment load from 1 to $210^{9} \mathrm{t}$ $\mathrm{yr}^{-1}$ [53] to $0.810^{9} \mathrm{t}$ [Meybeck, pers. comm.].

In addition to removal via mineralization, FOC can be removed from the global FOC transport budget through deposition and storage in continental reservoirs (term D in Eq. (6)). FOC storage and flux are controlled by many factors, including geology, relief, and climate. Geology influences FOC storage and flux by controlling relief, rock types, and diagenesis of FOM. Steep topographic relief increases the sediment load in rivers [54], [55] and [56], increasing delivery of FOC to the oceans [15].

Climate has a large influence on resuspension and sediment storage (terms C and D) as well as on mineralization (term E). Climate controls runoff [57]; more runoff results in an increased suspended sediment load [57] and thereby an increase in FOC flux to the world's 
oceans. By affecting runoff, land cover, soil type, and micro-organism populations, climate controls the aggressiveness of mineralization processes. Climate also affects the yield of FOC from the chemical weathering of rocks (term A) by controlling rainfall.

The fate processes of FOC deposition and mineralization are closely linked. FOC deposition creates a positive feedback for mineralization, in that the longer the residence time in a continental reservoir the greater the intensity of mineralization. Sequestration of FOC tends to occur in the floodplains of large drainage basins rather than in small mountainous drainage basins [15], for which sequestration occurs in shelf/slope sediments offshore of the river mouth.

\subsection{FOC production and removal in a river basin: The example of the Amazon River}

The processes controlling the FOC transport budget can be examined by evaluating the production and fate of FOC in the Amazon River basin. On the basis of the model presented here, of the world's 40 largest river basins, the Amazon has the highest FOC input flux resulting from weathering (term A in Eq. (6)) - close to $25 \%$ of the modelled global flux-but the POC associated with the suspended load at the mouth of the Amazon is dominated essentially by recent soil OM rather than refractory OM [58] and [59].

There are several potential explanations for the discrepancy between the FOC input flux from rocks in the Amazon basin and the delivery from this basin to the marine environment. A large river basin such as the Amazon has an enormous storage capacity [15], increasing the FOC residence time in the continental surface and thus its potential for mineralization.

One explanation is that shale outcrops, which cover about $50 \%$ of the watershed surface area, are located mainly in the lowlands of the drainage basin, where transport of the material resulting from the chemical weathering of these FOC-rich rocks is limited [60] and [61]. As demonstrated by the model presented here, the weathering of shales produces a large amount of FOC relative to other rock types. In contrast, rocks weathering in the Andean (mountainous) part of the basin are in an area where sediment transport capacity exceeds production. The majority of the Amazon sediment load thus comes from the Andean rivers [61], diluting FOC-rich lowland sediment. Further, deep weathering profiles in the lowlands may result in decreased chemical weathering of rocks in this area, limiting the FOC input to the surface.

Storage of FOC in the Amazon piedmont plain (term D in Eq. (6)) may also limit the output of FOC at the river's mouth. The maximum FOC fluxes occur in the area of the Andean cordillera (Fig. 3), where intense erosion feeds the Amazon basin lowlands. However, the presence of some weakly eroded thick and aged soils in the piedmont of the cordillera [62] suggests that an unknown but substantial amount of material originating from the Andes may be stored here, trapping and weathering FOC.

Intense mineralization of FOC in Amazon tributaries, soils [58], or floodplains (term D in Eq. (6), [59]) might also play a role in explaining the difference between FOC input and output fluxes from the Amazon basin. Extreme mineralization of FOC leads to the production of humic compounds [46], [63] and [64]; these humic compounds may become mixed with those in recent OM, such that the resulting DOC, which accounts for $62 \%$ of the total OC export [65], might contain a substantial proportion of FOC. This FOC would not be taken into 
account when quantifying the total FOC output from the river basin. For fine POC, which represents $34 \%$ of the global export of OM [65], the FOC contained is likely diluted by soil derived OM and other refractory OM [58], including kerogen, to the point that it is not identifiable.

Finally, it is possible that the FOC output flux from the Amazon basin is underestimated because of confusion of FOC with charred particles (black carbon inherited from the combustion of modern vegetation). Such confusion has been demonstrated for recent oceanic sediment from the northwest Atlantic Ocean [8]. This confusion may also occur in soils, as it was demonstrated that black carbon stays preferentially on the ground and is incorporated into soils [66] where it can mix with FOC. A reassessment of black carbon in recent sediments and soils might be required.

The example of the Amazon basin illustrates the uncertainty surrounding the removal of FOC from the global FOC transport budget (terms D and E in Eq. (6)). The estimate of FOC storage in and flux through carbon reservoirs in continental surfaces might require revision. Clearly, further investigation is required to better understand the relations between climate, geologic setting, and the nature of FOC.

\section{Conclusions}

By providing a first estimate of the spatial distribution of FOC and its flux derived from chemical weathering on a global scale, this study lays the foundation for investigating FOC delivery and occurrence in continental surfaces. The work presented here, coupled with the results of other investigations [13], provides estimates of the delivery of FOC to continental surfaces.

In the continental surface at the global scale, the modelled storage of FOC is $110010^{9} \mathrm{t}$, and the annual flux resulting from the weathering of sedimentary rock is $4310^{6} \mathrm{t}$. The Amazon drainage basin, with a modelled flux of FOC of about $10.7010^{6} \mathrm{t}$ resulting from the weathering of rocks, controls FOC input at a global scale. In relation to other OC fluxes in continental surface, the global modelled flux is significant and raises some fundamental questions whose answers might be found in the foreseeable future. First, the amount of organic carbon stored in soils requires re-evaluation if even a part of this fossil component can be mineralized. Consequently a re-evaluation of black carbon in soils also is required, as black carbon and FOC frequently occur together and exhibit the same physical and chemical properties. Second, the amount of organic carbon transported by fluvial systems requires reassessment taking into consideration the fossil component, which often is ignored in the literature. Hence, in the course of its supergene passage on the earth's surface, FOC can be mixed with present day organic carbon and black carbon in recent marine sediments and start a new carbon geological cycle. Recycled vitrinites, an organic gel-like material that frequently are observed in sedimentary rocks by organic petrographers [67], is evidence of such a loop in the carbon cycle.

These results indicate that the role of FOC in the global carbon cycle must be evaluated by the study of its fate in continental surfaces. Further, a focus on mineralization processes is required, including the parameters involved, and on quantification of the different fluxes between reservoirs, which are controlled by climate, geology, and anthropogenic activities, as well as mechanical erosion. Those more investigation is required to better understand the interactions between these forcing factors and the nature of FOC, and hence to quantify the 
terms in Eq. (6). These forcing factors have fluctuated over the course of geologic history and humans might have drastically modified and will continue to modify the input and the fate of FOC in continental surfaces.

\section{Acknowledgement}

This work was carried out under the auspices of the programme PNSE from CNRS-INSU. We are grateful to Wolfgang Ludwig (UMR CNRS 5110 CEFREME) for providing numerical data for the global drainage map, Anne Motelay-Massei (UMR CNRS 6143 M2C) and Michel Meybeck (UMR CNRS 7619 SYSIPHE) for the discussion of these results. We are grateful to Barbara Mahler (USGS, Austin, Texas) for her editorial assistance. We would thank an anonymous reviewer and Steven Petsch who has greatly improved the manuscript by offering his precious assistance.

\section{References}

[1] B. Tissot and D.H. Welte, Petroleum Formation and Occurrence, A New Approach of Gas Exploration, Springer-Verlag, Berlin (1978).

[2] R.A. Berner, Biogeochemical cycles of carbon and sulfur and their effect on atmospheric oxygen over Phanerozoic time, Palaeogeogr. Palaeoclimatol. Palaeoecol. 75 (1989), pp. 97 122.

[3] H.A. Johnson and B.W. Thomas, Report of the committee on the microscopic organisms in the boulder clays of Chicago and vinicity, Chicago Acad. Sci. Bull. 1 (1884), pp. 35-40.

[4] S.J. Kao and K.K. Liu, Particulate organic carbon export from a subtropical mountainous river (Lanyang His) in Taiwan, Limnol. Oceanogr. 41 (1996), pp. 1749-1757.

[5] P.A. Raymond and J.E. Bauer, Riverine export of aged terrestrial organic matter to the North Atlantic Ocean, Nature 409 (2001), pp. 497-500.

[6] P.A. Raymond, J.E. Bauer, N.F. Caraco, J.J. Cole, B. Longworth and S.T. Petsch, Controls on the variability of organic matter and dissolved inorganic carbon ages in the northeast US rivers, Mar. Chem. 92 (2004), pp. 353-366

[7] E. Lichtfouse, H. Budzinski, P. Garrigues and T. Eglinton, Ancient polycyclic aromatic hydrocarbons in modern soils: ${ }^{13} \mathrm{C},{ }^{14} \mathrm{C}$ and biomarkers evidence, Org. Geochem. 26 (1997), pp. 5-6.

[8] A.F. Dickens, Y. Gélinas, C.A. Masiello, S. Wakeham and J.I. Hedges, Reburial of fossil organic carbon in marine sediments, Nature 427 (2004), pp. 336-339.

[9] T. Komada, E.R.M. Druffel and S.E. Trumbore, Oceanic export of relict carbon by small mountainous river, Geophys. Res. Lett. 31 (2004), p. L07504. 
[10] H. Eswaran, E. Van den Berg and P. Reich, Organic carbon in soils of the world, J. Soil Sci. Soc. Amer. 57 (1993), pp. 192-194.

[11] W. Ludwig, J.L. Probst and S. Kempe, Predicting the oceanic input of organic carbon by continental erosion, Glob. Biogeochem. Cycles 10 (1996), pp. 23-41.

[12] J.A. Aitkenhead and W.H. McDowell, Soil C:N ratio as a predictor of annual riverine DOC fluxes at local and global scales, Glob. Biogeochem. Cycles 14 (2000), pp. 127-138.

[13] M. Meybeck, C, N and P in rivers. In: R. Wollast, F.T. McKenzie and L. Chou, Editors, Interaction of $C, N, P$, and $S$, Biogeochemical Cycles on Global Change, Springer, Berlin (1993), pp. 163-193.

[14] N.E. Blair, E.L. Leithold, S.T. Ford, K.A. Peeler, J.C. Holmes and D.W. Perkey, The persistence of memory: the fate of ancient sedimentary organic carbon in a modern sedimentary system, Geochim. Cosmochim. Acta 61 (2003), pp. 63-73.

[15] N.E. Blair, E.L. Leithold and R.C. Aller, From bedrock to burial: the evolution of particulate organic carbon across coupled watershed-continental margin systems, Mar. Chem. 92 (2004), pp. 141-156.

[16] M.W.I. Schmidt and A.G. Noack, Black carbon in soils and sediments: analysis, distribution, implications and current challenges, Glob. Biogeochem. Cycles 14 (2000), pp. 777-793.

[17] Ch. Di-Giovanni, J.R. Disnar and J.J. Macaire, Estimation of the annual yield of organic carbon released from carbonates and shales by chemical weathering, Glob. Planet. Change 32 (2002), pp. 195-210.

[18] Ph. Amiotte-Suchet, J.L. Probst and W. Ludwig, Worldwide distribution of continental rock lithology: implications for the atmospheric/soil $\mathrm{CO} 2$ uptake by continental weathering and alkalinity river transport to the oceans, Glob. Biogeochem. Cycles 17 (2003).

[19] W. Ludwig, Ph. Amiotte-Suchet, G. Munhoven and J.L. Probst, Atmospheric CO2 consumption by continental erosion: present-day control and implications for the Last Glacial Maximum, Glob. Planet. Change 16-17 (1998), pp. 107-120.

[20] A.B. Ronov and A.A. Yaroshevsky, A new model for the chemical structure of the Earth crust, Geochem. Int. 13 (1976), pp. 1761-1795.

[21] Y. Berton and P. Le Berre, Guide de prospection des matériaux de carrière, Manuels et Méthodes vol. 5, BRGM, Orléans (1995).

[22] Ph. Amiotte-Suchet and J.L. Probst, A global model for present-day atmospheric/soil $\mathrm{CO}_{2}$ consumption by chemical erosion of continental rocks $\left(\mathrm{GEM}-\mathrm{CO}_{2}\right)$, Tellus 47B (1995), pp. 273-280.

[23] M. Meybeck, Composition chimique des ruisseaux non pollués de France, Sci. Géol., Bull. 39 (1986), pp. 3-77. 
[24] $\mathrm{Ph}$. Amiotte-Suchet and J.L. Probst, Flux de $\mathrm{CO}_{2}$ consommé par altération chimique continentale: influence du drainage et de la lithologie, C. R. Acad. Sci. Paris 317 (1993), pp. 615-622.

[25] R.M. Garrels and F.T. MacKenzie, Evolution of Sedimentary Rocks, Norton \& Co. Inc., New York (1971).

[26] Ch. Di-Giovanni and M. Campy, Disnar, Des particules charbonneuses, témoins des variations de l'érosion chimique d'un bassin versant calcaire durant l'holocène (bassin de chaillexon, doubs, France), C. R. Acad. Sci. Paris 328 (1999), pp. 167-172.

[27] Ch. Di-Giovanni, J.R. Disnar, J.P. Bakyono, D. Keravis, F. Millet and J.E. Olivier, Application de l'étude de la matière organique à l'analyse de l'érosion: exemple du bassin versant du Moulin, dans les terres noires des Alpes-de-Haute-Provence (France), C. R. Acad. Sci. 331 (2000), pp. 7-14.

[28] H. Noël, E. Garbolino, A. Brauer, E. Lallier-Vergès, J.L. de Beaulieu and J.R. Disnar, Human impact and soil erosion during the last 5000 yrs as recorded in lacustrine sedimentary organic matter at Lac d'Annecy, the French Alps, J. Paleolimnol. 25 (2001), pp. 229-244.

[29] D. Sebag, Y. Copard, Ch. Di-Giovanni, A. Durand, B. Laignel, S. Ogier and E. Vergès, Palynofacies as a tool to study origins and transfers of particulate organic matter in recent terrestrial environments: synopsis and prospects, Earth Sci. Rev. 79 (2006), pp. 241-259.

[30] Y. Copard, F. Pezet, Ch. Di-Giovanni and T.J. Coulthard, Estimation of Storage and Fluxes of Recent and Fossil Organic Carbon in an Alpine Catchment (Montmin, HauteSavoie, France), Oral Presentation for European Geologist Union, Wien (2007).

[31] Y. Copard, Ch. Di-Giovanni, T. Martaud, P. Albéric and J.E. Ollivier, Using Rock-Eval 6 pyrolysis for tracking fossil organic carbon in modern environments: implications for the roles of erosion and weathering, Earth Surf. Process. Landf. 31 (2006), pp. 135-153

[32] C.A. Massiello and E.R.M. Druffel, Carbon isotope geochemistry of the Santa Clara River, Glob. Biogeochem. Cycles 15 (2001), pp. 407-416.

[33] B. Gomez, N.A. Trustrum, D.M. Hicks, K.M. Rogers, M.J. Page and K.R. Tate, Production, storage and output of particulate organic carbon: Waipaoa River basin, New Zealand, Water Resour. Res. 39 (2003), pp. 2-8.

[34] L. Megens, J. Van Der Plicht and J.W. De Leeuw, Temporal variations in ${ }^{13} \mathrm{C}$ and ${ }^{14} \mathrm{C}$ concentrations in particulate organic matter from the southern North Sea, Geochim. Cosmochim. Acta 65 (2001), pp. 2899-2911.

[35] M.A. Goñi, K.C. Ruttenberg and T.I. Eglinton, A reassessment of the sources and importance of land-derived organic matter in surface sediments from the Gulf of Mexico, Geochim. Cosmochim. Acta 62 (1998), pp. 3055-3075.

[36] E.S. Gordon and M.A. Goñi, Sources and distribution of terrigenous organic matter delivered by the Atchafalaya River to sediments in the northern Gulf of Mexico, Geochim. Cosmochim. Acta 67 (2003), pp. 2359-2375. 
[37] F. Gadel and J.P. Ragot In: B. Tissot and F. Bienner, Editors, Sur l'allochtonie de la fraction organique particulaire des dépôts quaternaires récents du Golfe du Lion, Adv. Org. Geochem. vol. 21 (1973), pp. 619-628.

[38] X. Jiongxin, Erosion caused by hyperconcentrated flow on the Loess Plateau of China, Catena 36 (1999), pp. 1-19

[39] M. Meybeck, Origins and behaviour of carbon species in world rivers. In: E. Roose, R. Lal, C. Feller, B. Barthès and B.A. Stewart, Editors, Erosion and Carbon Dynamics, Adv. Soil Sci. Series, CRC Boca Raton (2005), pp. 209-238.

[40] C. Valentin, J. Poesen and Y. Li, Gully erosion: impacts, factors and control, Catena 63 (2005), pp. 132-153

[41] L.M. Mayer, Relationships between mineral surfaces and organic carbon concentrations in soils and sediments, Chem. Geol. 114 (1994), pp. 347-363.

[42] L.M. Mayer, Surface area control of organic carbon accumulation in continental shelf sediments, Geochim. Cosmochim. Acta 58 (1994), pp. 1271-1284.

[43] J.I. Hedges and R.G. Keil, Sedimentary organic matter preservation: an assessment and speculative synthesis, Mar. Chem. 49 (1995), pp. 81-115.

[44] J.J. Middelburg, J. Nieuwenhuize and P. Van Breugel, Black carbon in marine sediments, Mar. Chem. 65 (1999), pp. 245-252.

[45] S.T. Petsch, R.A. Berner and T.I. Eglinton, A field study of the chemical weathering of ancient sedimentary organic matter, Org. Geochem. 31 (2000), pp. 475-487.

[46] P.M. Fredericks, P. Warbrooke and M.A. Wilson, Chemical changes during natural oxidation of a high volatile bituminous coal, Org. Geochem. 5 (1983), pp. 89-97.

[47] H.B. Lo and B.J. Cardott, Detection of natural weathering of Upper Mc Alester and Woodford shale, Oklahoma, U.S.A. Org. Geochem. 22 (1995), pp. 73-83.

[48] Y. Copard, J.R. Disnar and J.F. Becq-Giraudon, Erroneous maturity assessment given by Tmax and HI Rock-Eval parameters on highly mature weathered coals, Int. J. Coal Geol. 49 (2002), pp. 57-65

[49]D.W. Van Krevelen, Coal, typology, chemistry, physics, constitution, Coal Science and Technology (2nd edition), Elsevier, Amsterdam (1981).

[50] S.T. Petsch, R.J. Smernik, T.I. Eglinton and J.M. Oades, A solid state ${ }^{13}$ C-NMR study of kerogen degradation during black shale weathering, Geochim. Cosmochim. Acta 65 (2001), pp. 1867-1882.

[51] D.L. Higgitt and X.X. Lu, Sediment delivery to the three gorges: 1. Catchment controls, Geomorphology 41 (2001), pp. 143-156. 
[52] E.M. Latrubese, J.C. Stevaux and R. Sinha, Tropical rivers, Geomorpholgy 70 (2005), pp. 187-206.

[53] W.W. Hay, Detrital sediment fluxes from continents to oceans, Chem. Geol. 145 (1998), pp. 287-323.

[54] P. Pinet and M. Souriau, Continental erosion and large-scale relief, Tectonics 7 (1988), pp. 563-582.

[55] J.D. Milliman and P.M. Syvitski, Geomorphic/tectonic control of sediment discharge to the ocean: the importance of small mountainous rivers, J. Geol. 100 (1992), pp. 525-544.

[56] M.A. Summerfield and N.J. Hulton, Natural controls of fluvial denudation rates in major world drainage basins, J. Geophys. Res. 99 (1994), pp. 13,871-13,883.

[57] J.D. Milliman and R.H. Meade, Worldwide delivery of river sediment to the oceans, $J$. Geol. 91 (1983), pp. 1-21.

[58] J.I. Hedges, W.A. Clarke, P.D. Quay, J.E. Richey, A.H. Devol and U.M. de Santos, Compositions and fluxes of particulate organic material in the Amazon River system, Limnol. Oceanogr. 31 (1986), pp. 717-738.

[59] E. Mayorga, A.K. Aufdenkampe, C.A. Massiello, A.V. Krusche, J.I. Hedges, P.D. Quay, J. Richey and T.A. Brown, Young organic matter as a source of carbon dioxide outgasing from Amazonian rivers, Nature 436 (2005), pp. 538-541.

[60] R.F. Stallard and J.M. Edmond, Geochemistry of the Amazon, 2. The influence of geology and weathering environment on the dissolved load, J. Geophys. Res. 88 (1983), pp. 9671-9688.

[61] J. Gaillardet, B. Dupré, C.J. Allègre and Ph. Négrel, Chemical and physical denudation in the Amazon River Basin, Chem. Geol. 142 (1997), pp. 141-173

[62] R.F. Stallard, Relating chemical and physical erosion, Rev. Min. 31 (1995), pp. 543-564.

[63] G.R. Ingram and J.D. Rimstidt, Natural weathering of coal, Fuel 63 (1984), pp. 292-296.

[64] W.H. Mathews and R.M. Bustin, Changes associated with natural in situ weathering of a coking coal from southeastern British Columbia, Fuel 63 (1984), pp. 548-550.

[65] J.E. Richey, J.I. Hedges, A.H. Devol, P.D. Quay, R. Victoria, L. Martinelli and B.R. Forsberg, Biogeochemistry of carbon in the Amazon River, Limnol. Oceanogr. 35 (1990), pp. $352-371$.

[66] T.A.J. Kuhlbusch and P.J. Crutzen, Toward a global estimate of black carbon in residues of vegetation fires representing a sink of atmospheric $\mathrm{CO}_{2}$ and a source of $\mathrm{O}_{2}, G l o b$.

Biogeochem. Cycles 9 (1995), pp. 491-501.

[67] P. Nzoussi-Mbassani, Y. Copard and J.R. Disnar, Recycled vitrinites: diagnostic and criteria, Int. J. Coal Geol. 61 (2005), pp. 223-239. 
[68] G.J. Chakrapani and V. Subramanian, Rates of erosion and sedimentation in the Mahanadi river basin, India, J. Hydrobiol. 149 (1993), pp. 39-48. 


\section{Figures}

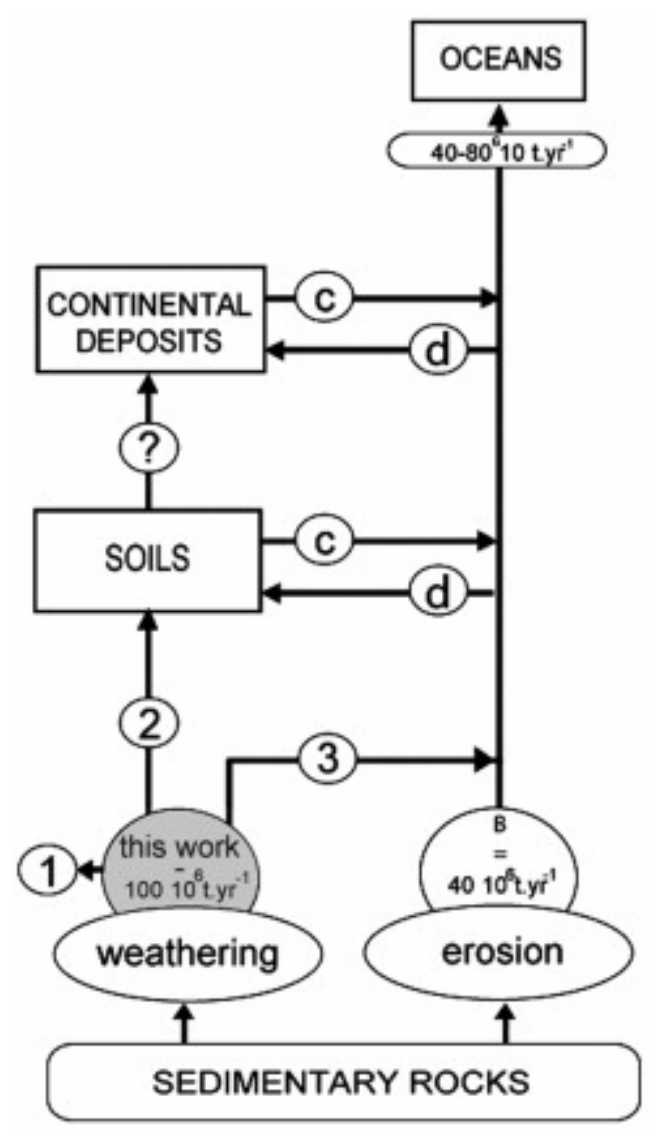

Fig. 1. Relations and exchanges of FOC within continental surfaces. The letters refer to terms in Eq. (6): FOC fluxes from weathering of rocks, from [17] and this study $(A)$; FOC fluxes from erosion for mountainous coastal catchments [14] and other world rivers (not quantified) $(B)$; FOC supplied from the remobilisation processes $(C)$; deposition of FOC in continental reservoirs $(D)$; mineralization occurring during transport of FOC (black arrows) and within reservoirs $(E)$. FOC main fate processes after release by chemical weathering indicated by (1) mineralization; (2) input to soils; (3) direct input to rivers. 


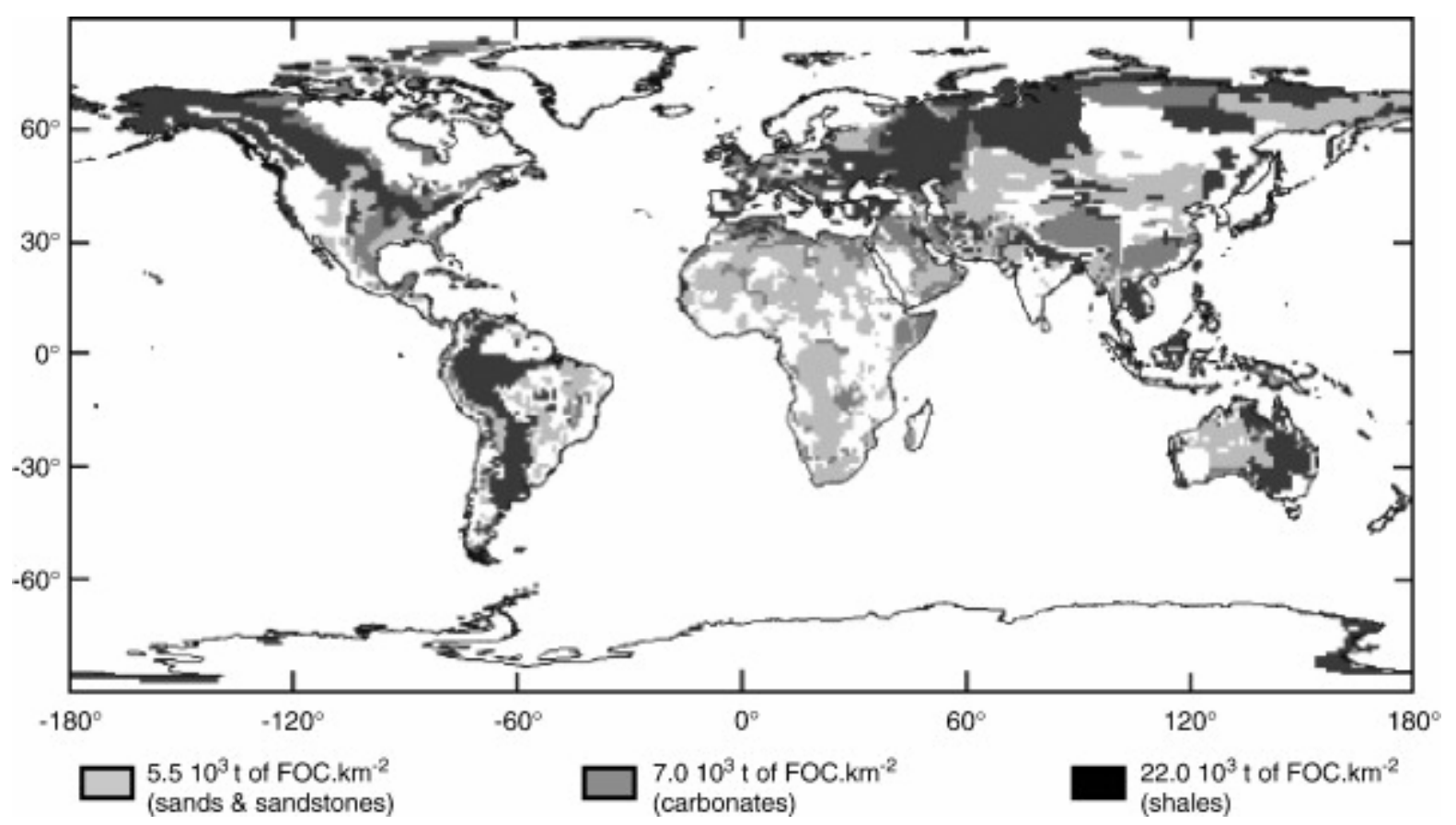

Fig. 2. Estimated storage $\left(\times 10^{3} \mathrm{t} \mathrm{km}^{-2}\right)$ of FOC in the first meter of sedimentary rock for the entire continental surface. Values shown are for sand/sandstone, carbonates, and shales, and were calculated using the average total organic carbon for these rock type (see Table 1).

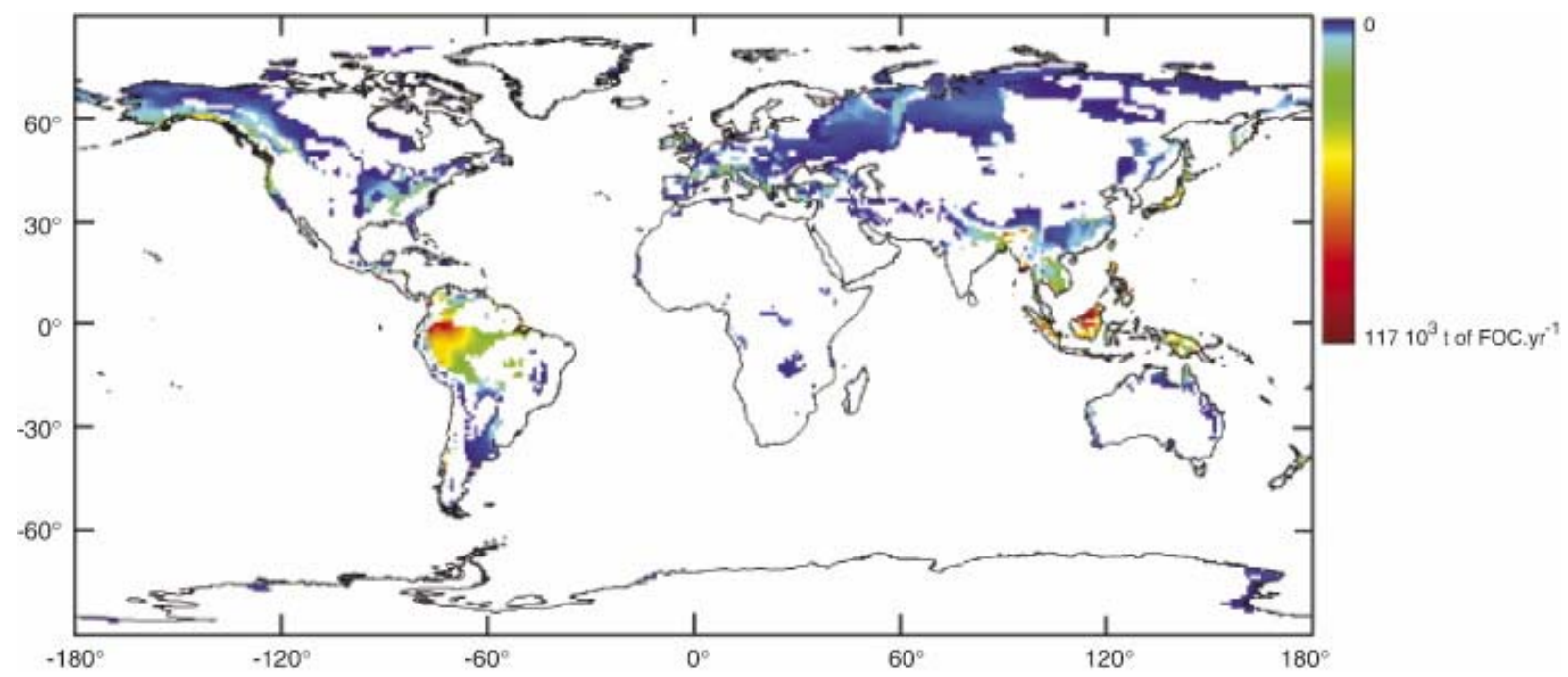

Fig. 3. Annual FOC fluxes for each grid cell $\left(1^{\circ} \times 1^{\circ}\right.$ resolution, in $\left.10^{3} \mathrm{t} \mathrm{yr}^{-1}\right)$ delivered by chemical weathering of carbonate and shale for the entire continental surface. Values were calculated on the basis of the $\mathrm{CO}_{2}$ consumption by rock weathering. Tropical climatic zones near the equator provide most of the FOC yielded by rock weathering. 

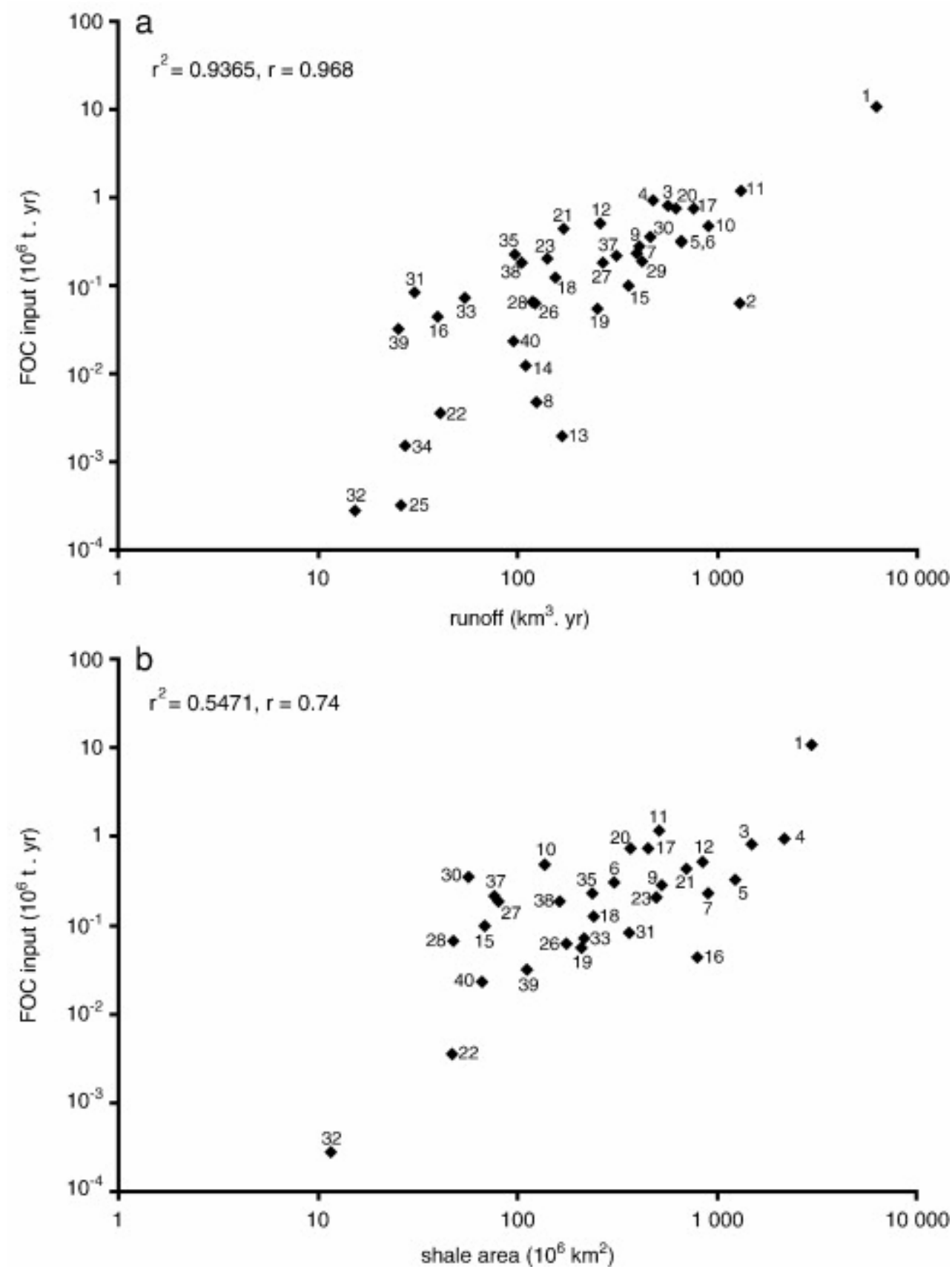

Fig. 4. Correlation between a) runoff and FOC input (values from Table 2) on a log-log scale; b) areal extent of shale and FOC input (values from Table 2) on a log-log scale. Statistical parameters indicate that FOC yield is more sensitive to runoff than to the areal extent of shale. 


\section{Tables}

Table 1. : Description and the main rock parameters used in this study (proportion of rocks and lithological description [18], OC content [20] and density [21])

\begin{tabular}{|l|l|l|l|l|}
\hline & \begin{tabular}{l} 
Proportions on continental surface \\
\hline
\end{tabular} & $\begin{array}{l}\text { OC content } \\
\mathbf{( \% )}\end{array}$ & Density & Lithological description \\
\hline & $\mathbf{( w t . \% )}$ & & & \\
\hline Shales & 25.4 & 1.00 & 2.2 & \\
\hline Carbonates & 13.4 & 0.28 & 2.5 & Clastic and argilaceous sediments (poorly carbonated) \\
\hline Sand and sandstones & 26.2 & 0.24 & 2.1 & All rocks with more $>50 \%$ of carbonates minerals \\
\hline
\end{tabular}

Table 2. : Budget of FOC stock and flux from the chemical weathering of shales and carbonates of the 40 major river drainage basins ranged following decreasing area

\begin{tabular}{|c|c|c|c|c|c|c|c|c|c|c|}
\hline \multirow[b]{2}{*}{ Basins } & \multirow[b]{2}{*}{ Number } & \multirow[b]{2}{*}{ Area } & \multirow[b]{2}{*}{ Runoff } & \multicolumn{3}{|c|}{$\begin{array}{l}\text { Areal extent (in } 10^{6} \mathrm{~km}^{2} \text {, from the lithologic abundance in } \% \text { of } \\
\text { the basin area) }\end{array}$} & \multirow[b]{2}{*}{$\begin{array}{l}\text { FOC } \\
\text { stock }\end{array}$} & \multirow[b]{2}{*}{$\begin{array}{l}\text { FOC input by } \\
\text { carbonates }\end{array}$} & \multirow[b]{2}{*}{$\begin{array}{l}\text { FOC input by } \\
\text { shales }\end{array}$} & \multirow[b]{2}{*}{$\begin{array}{l}\text { Global FOC } \\
\text { input }\end{array}$} \\
\hline & & & & Carbonates & Shales & Sands and sandstones & & & & \\
\hline & & $\left(10^{6} \mathrm{~km}^{2}\right)$ & $\left(\mathbf{k m}^{3}\right.$ & & & & $\left(10^{9} t\right)$ & $\left(10^{6} \mathrm{tyr}^{-1}\right)$ & $\left(10^{6} t_{y r^{-1}}\right)$ & $\left(10^{6} \mathrm{tyr}^{-1}\right)$ \\
\hline Amazon & 1 & 5.846 & 6223 & 228.0 & $2,963.9$ & 976.3 & 73 & 0.159 & 10.583 & 10.741 \\
\hline Congo & 2 & 3.665 & 1298 & 370.1 & 0.0 & $1,707.7$ & 12 & 0.064 & - & 0.064 \\
\hline Mississipi & 3 & 3.156 & 570 & 571.2 & 1502.1 & 798.4 & 41 & 0.082 & 0.732 & 0.814 \\
\hline $\mathrm{Ob}$ & 4 & 3.010 & 477 & 81.3 & 2164.0 & 595.9 & 51 & 0.005 & 0.933 & 0.938 \\
\hline Parana & 5 & 2.835 & 666 & 34.0 & 1244.6 & 774.0 & 32 & 0.003 & 0.322 & 0.324 \\
\hline Yenisey & 6 & 2.488 & 665 & 171.7 & 306.0 & 159.2 & 8 & 0.055 & 0.251 & 0.305 \\
\hline
\end{tabular}




\begin{tabular}{|c|c|c|c|c|c|c|c|c|c|c|}
\hline \multirow{3}{*}{ Basins } & \multirow[b]{2}{*}{ Number } & \multirow[b]{2}{*}{ Area } & \multirow[b]{2}{*}{ Runoff } & \multicolumn{3}{|c|}{$\begin{array}{l}\text { Areal extent (in } 10^{6} \mathrm{~km}^{2} \text {, from the lithologic abundance in } \% \text { of } \\
\text { the basin area) }\end{array}$} & \multirow[b]{2}{*}{$\begin{array}{l}\text { FOC } \\
\text { stock }\end{array}$} & \multirow[b]{2}{*}{$\begin{array}{l}\text { FOC input by } \\
\text { carbonates }\end{array}$} & \multirow[b]{2}{*}{$\begin{array}{l}\text { FOC input by } \\
\text { shales }\end{array}$} & \multirow[b]{2}{*}{$\begin{array}{l}\text { Global FOC } \\
\text { input }\end{array}$} \\
\hline & & & & Carbonates & Shales & Sands and sandstones & & & & \\
\hline & & $\left(10^{6} \mathrm{~km}^{2}\right)$ & $\begin{array}{l}\left(\mathrm{km}^{3}\right. \\
\left.\mathrm{yr}^{-1}\right)\end{array}$ & & & & $\left(10^{9} t\right)$ & $\left(10^{6} \mathrm{tyr}^{-1}\right)$ & $\left(10^{6} \mathrm{tyr}^{-1}\right)$ & $\left(10^{6} \mathrm{tyr}^{-1}\right)$ \\
\hline Lena & 7 & 2.337 & 393 & 261.7 & 904.4 & 252.4 & 22 & 0.022 & 0.211 & 0.233 \\
\hline Nile & 8 & 1.910 & 125 & 47.8 & 0.0 & 609.3 & 4 & 0.005 & - & 0.005 \\
\hline Amur & 9 & 1.895 & 407 & 0.0 & 530.5 & 225.5 & 13 & - & 0.284 & 0.284 \\
\hline Yangtze & 10 & 1.746 & 908 & 768.2 & 137.9 & 242.7 & 10 & 0.264 & 0.210 & 0.474 \\
\hline Ganges-Brahmaputra & 11 & 1.637 & 1,313 & 553.1 & 515.5 & 252.0 & 17 & 0.145 & 1.030 & 1.175 \\
\hline MacKenzie & 12 & 1.564 & 260 & 322.2 & 843.0 & 0.0 & 19 & 0.022 & 0.491 & 0.513 \\
\hline Niger & 13 & 1.504 & 166 & 94.8 & 0.0 & 869.6 & 5 & 0.002 & - & 0.002 \\
\hline Zambeze & 14 & 1.370 & 109 & 186.3 & 0.0 & 628.6 & 5 & 0.012 & - & 0.012 \\
\hline Saint-Laurent & 15 & 1.131 & 360 & 281.7 & 69.0 & 0.0 & 3 & 0.052 & 0.047 & 0.099 \\
\hline Murray-Darling & 16 & 1.109 & 40 & 0.0 & 801.7 & 10.0 & 18 & - & 0.044 & 0.044 \\
\hline Orinoco & 17 & 0.972 & 759 & 12.6 & 455.1 & 172.1 & 11 & 0.001 & 0.747 & 0.749 \\
\hline Tigris-Euphrates & 18 & 0.934 & 156 & 396.9 & 241.0 & 160.6 & 9 & 0.033 & 0.093 & 0.126 \\
\hline Indus & 19 & 0.877 & 251 & 228.1 & 210.6 & 147.4 & 7 & 0.025 & 0.030 & 0.055 \\
\hline Mekong & 20 & 0.855 & 623 & 182.9 & 369.3 & 71.8 & 9 & 0.073 & 0.669 & 0.742 \\
\hline Yukon & 21 & 0.816 & 169 & 0.0 & 696.8 & 0.0 & 14 & - & 0.440 & 0.440 \\
\hline Huang He & 22 & 0.795 & 41 & 60.4 & 46.9 & 219.4 & 3 & 0.003 & 0.001 & 0.004 \\
\hline Danube & 23 & 0.741 & 140 & 107.5 & 494.4 & 24.5 & 12 & 0.021 & 0.182 & 0.203 \\
\hline
\end{tabular}




\begin{tabular}{|c|c|c|c|c|c|c|c|c|c|c|}
\hline \multirow{3}{*}{ Basins } & \multirow[b]{2}{*}{ Number } & \multirow[b]{2}{*}{ Area } & \multirow[b]{2}{*}{ Runoff } & \multicolumn{3}{|c|}{$\begin{array}{l}\text { Areal extent (in } 10^{6} \mathrm{~km}^{2} \text {, from the lithologic abundance in } \% \text { of } \\
\text { the basin area) }\end{array}$} & \multirow[b]{2}{*}{$\begin{array}{l}\text { FOC } \\
\text { stock }\end{array}$} & \multirow[b]{2}{*}{$\begin{array}{l}\text { FOC input by } \\
\text { carbonates }\end{array}$} & \multirow[b]{2}{*}{$\begin{array}{l}\text { FOC input by } \\
\text { shales }\end{array}$} & \multirow[b]{2}{*}{$\begin{array}{l}\text { Global FOC } \\
\text { input }\end{array}$} \\
\hline & & & & Carbonates & Shales & Sands and sandstones & & & & \\
\hline & & $\left(10^{6} \mathrm{~km}^{2}\right)$ & $\begin{array}{l}\left(\mathrm{km}^{3}\right. \\
\left.\mathrm{yr}^{-1}\right)\end{array}$ & & & & $\left(10^{9} t\right)$ & $\left(10^{6} \mathrm{tyr}^{-1}\right)$ & $\left(10^{6} \mathrm{tyr}^{-1}\right)$ & $\left(10^{6} \mathrm{tyr}^{-1}\right)$ \\
\hline Colorado & 24 & 0.674 & 28 & 0.0 & 0.0 & 374.8 & 2 & - & - & 0.000 \\
\hline Orange & 25 & 0.663 & 26 & 64.9 & 0.0 & 455.9 & 3 & 0.000 & - & 0.000 \\
\hline Kolyma & 26 & 0.637 & 122 & 0.0 & 176.3 & 460.3 & 6 & - & 0.062 & 0.062 \\
\hline Columbia & 27 & 0.623 & 269 & 0.0 & 80.3 & 8.7 & 2 & - & 0.184 & 0.184 \\
\hline Sao Francisco & 28 & 0.594 & 119 & 236.4 & 47.5 & 83.2 & 3 & 0.033 & 0.033 & 0.066 \\
\hline Xun Jiang (Pearl River) & 29 & 0.444 & 419 & 366.1 & 0.0 & 0.0 & 3 & 0.186 & - & 0.186 \\
\hline Irrawaddy & 30 & 0.402 & 459 & 176.9 & 56.7 & 123.0 & 3 & 0.105 & 0.249 & 0.355 \\
\hline Don & 31 & 0.387 & 31 & 22.8 & 363.8 & 0.0 & 8 & 0.002 & 0.082 & 0.084 \\
\hline Senegal & 32 & 0.365 & 15 & 0.0 & 11.7 & 235.2 & 2 & - & 0.000 & 0.000 \\
\hline Indigirka & 33 & 0.362 & 54 & 0.0 & 217.4 & 144.3 & 5 & - & 0.072 & 0.072 \\
\hline Limpopo & 34 & 0.315 & 27 & 44.7 & 0.0 & 78.7 & 1 & 0.002 & - & 0.002 \\
\hline North Dvina & 35 & 0.303 & 97 & 32.8 & 237.8 & 33.1 & 6 & 0.006 & 0.219 & 0.226 \\
\hline Godaravi & 36 & 0.299 & 147 & 0.0 & 0.0 & 11.6 & 0 & - & - & 0.000 \\
\hline Magdalena & 37 & 0.267 & 313 & 12.8 & 76.1 & 63.6 & 2 & 0.010 & 0.207 & 0.217 \\
\hline Fraser & 38 & 0.236 & 104 & 0.0 & 162.6 & 0.0 & 4 & - & 0.185 & 0.185 \\
\hline Yana & 39 & 0.225 & 25 & 0.0 & 111.1 & 113.8 & 3 & - & 0.032 & 0.032 \\
\hline Mehandi & 40 & 0.170 & 94 & 0.0 & 74.1 & 9.5 & 0 & - & 0.023 & 0.023 \\
\hline
\end{tabular}




\begin{tabular}{|c|c|c|c|c|c|c|c|c|c|c|}
\hline \multirow[b]{2}{*}{ Basins } & \multirow[b]{2}{*}{ Number } & \multirow[b]{2}{*}{ Area } & \multirow[b]{2}{*}{ Runoff } & \multicolumn{3}{|c|}{$\begin{array}{l}\text { Areal extent (in } 10^{6} \mathrm{~km}^{2} \text {, from the lithologic abundance in } \% \text { of } \\
\text { the basin area) }\end{array}$} & \multirow[b]{2}{*}{$\begin{array}{l}\text { FOC } \\
\text { stock }\end{array}$} & \multirow[b]{2}{*}{$\begin{array}{l}\text { FOC input by } \\
\text { carbonates }\end{array}$} & \multirow[b]{2}{*}{$\begin{array}{l}\text { FOC input by } \\
\text { shales }\end{array}$} & \multirow[b]{2}{*}{$\begin{array}{l}\text { Global FOC } \\
\text { input }\end{array}$} \\
\hline & & & & Carbonates & Shales & Sands and sandstones & & & & \\
\hline & & $\left(10^{6} \mathrm{~km}^{2}\right)$ & $\left(\mathbf{k m}^{3}\right.$ & & & & $\left(10^{9} t\right)$ & $\left(10^{6} \mathrm{tyr}^{-1}\right)$ & $\left(10^{6} \mathrm{tyr}^{-1}\right)$ & $\left(10^{6} \mathrm{tyr}^{-1}\right)$ \\
\hline Total 40 selected basins & & $\mathbf{5 0 . 1 7 7}$ & - & 5917.9 & 16112.1 & 11093.1 & 448 & 1.392 & 18.648 & 20.040 \\
\hline $\begin{array}{l}\text { Total continental surface } \\
\text { without ice }\end{array}$ & & 133.600 & - & - & - & - & 1061 & 3.160 & 39.744 & 42.904 \\
\hline
\end{tabular}


